\title{
Discrimination of Wild and Hatchery-Reared Black Porgy Acanthopagrus schlegelii Using Otolith Elements Analysis of Magnesium and Manganese
}

\author{
Weiche Chang1*, Chunhan Shih ${ }^{2 *}$, Huangan Lin ${ }^{1}$, Chiahui Wang3 , Pinghung Chang1,4, \\ Yingchou Lee ${ }^{1 \#}$ \\ ${ }^{1}$ Institute of Fisheries Science, College of Life Science, National Taiwan University, Taiwan \\ ${ }^{2}$ Institute of Oceanography, Minjiang University, Fuzhou, China \\ ${ }^{3}$ Department of Environmental Biology and Fisheries Science, National Taiwan Ocean University, Taiwan \\ ${ }^{4}$ Hualien Hsien Bureau of Agriculture, Taiwan \\ Email:
}

How to cite this paper: Chang, W.C., Shih, C., Lin, H.G., Wang, C.H., Chang, P.H. and Lee, Y.C. (2019) Discrimination of Wild and Hatchery-Reared Black Porgy Acanthopagrus schlegelii Using Otolith Elements Analysis of Magnesium and Manganese. Open Journal of Marine Science, 9, 18-32.

https://doi.org/10.4236/ojms.2019.91002

Received: December 6, 2018

Accepted: January 19, 2019

Published: January 22, 2019

Copyright $\odot 2019$ by author(s) and Scientific Research Publishing Inc. This work is licensed under the Creative Commons Attribution International License (CC BY 4.0).

http://creativecommons.org/licenses/by/4.0/

\section{(c) (i) Open Access}

\begin{abstract}
Due to the decreasing resources of both inshore and offshore fisheries, many organizations have released fry to enhance their stock in recent years. The discrimination between wild and hatchery-reared individuals must be performed to assess the efficiency of the release. Fresh groundwater is generally used by hatchers in southwestern Taiwan to decrease salinity and to promote the growth of larvae prior to feeding; thus, the elemental composition of the otolith may be different in stocks, and this difference may be used for identification. This study used Laser Ablation Inductively Coupled Plasma Mass Spectrometry (LA-ICPMS) to analyze the trace elements in the nuclei of otoliths from black porgy Acanthopagrus schlegelii, including six hatchery reared specimens from the Tainan County, three recaptured marked and ten captured unmarked specimens from the Miaoli County in Northwestern coast of Taiwan. Among the six hatchery and three recaptured marked specimens, which ranged from 4.9 to $23.4 \mathrm{~cm}$ in body length, the nucleus zone (relative to within $5 \mathrm{~cm}$ in size growth) of the otoliths showed higher magnesium concentrations than that observed on both edges. The distribution was similar to an inverse "V" shape. The otoliths also showed lower manganese concentrations near the nucleus and had higher values near the edges, resulting in a distribution similar to a "U" shape. According to the appeared shape of $\mathrm{Mg}^{2+} / \mathrm{Ca}^{2+}$ and $\mathrm{Mn}^{2+} / \mathrm{Ca}^{2+}$ ratio in the central area of the nucleus zone, this study determined six specimens which were from hatchery reared and three specimens were from wild among ten unmarked specimens captured from
\end{abstract}

*These authors contributed equally to this work. 
the Northwestern coast of Taiwan. Under the conditions used in this study, the absorption of calcium into the otolith was active and required energy in the seawater and freshwater, while the incorporation of magnesium and manganese was passive and was primarily affected by diffusion.

\section{Keywords}

Black Porgy, Hatchery-Reared, Otolith, Environmental Growth Marks, Trace Element, LA-ICPMS

\section{Introduction}

In recent years, the release of fry from hatcheries to the wild is a common method of enhancing Taiwan's natural fishery resources [1]. In the past, the effectiveness and parameters of fry stocking, including recapture rate, number of survivors and growth condition were rarely assessed because of the small size [2] and large number of releasing of the fry which is difficult to mark [3] [4] and lead to the low recovery rate [1] [5].

Black porgy Acanthopagrus schlegelii are distributed widely, from Japan and China to the coastal waters of Taiwan. A coastal euryhaline and demersal species, these fish are commonly reared in Taiwanese hatcheries [2]. Since 1988, the black porgy was one of the commonly hatchery-reared species used to enhance natural fishery resources in Taiwan [6]. However, the effectiveness of this large-scale fry stocking is rarely documented and studied [4]. The primary obstacle to documenting these fry is the difficulty in differentiating the hatchery-reared fish from the resident fish. Many methods have been used for the identification and discrimination of fish stock, including the mark-and-recapture method, physiological and behavioral characteristics, morphology, and biochemical and molecular biology techniques. These methods are useful but exhibit some disadvantages. Although some mark-and-recapture studies have been performed [4], they have encountered the following problems: 1) not all of the fish were marked by the mass marking process; 2) the fish may lose their marks after being released; 3 ) the same species of fry without a mark had been previously released in the same water area, making it impossible to differentiate between the hatchery-reared fish from the resident fish. Thus, we identified a method by which hatchery-reared individuals could be identified by studying their growth environment. It was difficult to distinguish between the wild and hatchery-reared stocks after they had been mixed. Studies using the mark-and-recapture method of identification have generally been expensive and time consuming [7]. In addition, some unmarked individuals were stocked prior to when the experiment was performed. To use the physiological and behavioral characteristics (e.g. migration, spawning time, sexual maturity, growth rate) for distinguishing stocks, an understanding of the species' life history is required [7]. Genetic markers can also be used to distinguish between stocks; however, 
these assays can also be expensive to apply, and high levels of gene flow between stocks have been found [8]. Previous studies in Taiwan have suggested that distinguishing reared stocks from wild stocks of black porgy by morphology and meristic characters is difficult. Thus, differentiating between the stocks requires a method beyond the traditional biological and morphological assays.

Otoliths, which grow in daily increments in fish [9], can accurately record physical and chemical environmental conditions [10]. Otolith microchemistry is a method that has been recently applied to stock identification [11] [12] [13], and it can provide an understanding of the environmental history of fish movements [14], population structure [15], and the identification of spawning estuaries [16]. Laser Ablation Inductively Coupled Plasma Mass Spectrometry (LA-ICPMS) [17] [18] is a precision tool which could be used to analyze trace elements with solid materials. The high power pulsed laser beam is focused at selected locations on the otolith. In the laser ablation sampling system, the otolith grinding surface is ablated by a high-energy laser, and then the ions are extracted with argon gas carried into the ICPMS for analysis [18] [19]. Previous studies have successfully discriminated among different stocks of Atlantic cod Gadus morhua using LA-ICPMS analysis of otolith nuclei, which demonstrated the variations in elemental concentrations [11]. The otolith forms in daily increments in larval-stage fish, with the first ring formed on the day of hatching [9]. Conversely, the external otolith reflects the wild environment after stocking. Microelements from the surrounding water bodies merge and precipitate onto the otolith, and other divalent ions (i.e. $\mathrm{Sr}^{2+}, \mathrm{Ba}^{2+}, \mathrm{Mg}^{2+}$, etc.) may replace $\mathrm{Ca}^{2+}$ in the otolith structure [20]. The elemental concentrations of the otolith are usually associated with the elemental concentrations of the surrounding water [21], and a positive correlation exists between these concentrations [22]. Changes in the chemical microelements can be used as an indicator of a fish's life history, which can reflect the stock migration or act as a natural geographical marker [23]. Earlier studies have also indicated that the measurement of microelements in otoliths may be useful to identify stocks [11] [24]. In the southwestern coastal area of Taiwan, the aquaculture hatcheries generally use groundwater due to the lack of fresh water [25] [26]. Groundwater interacts with organic matter and minerals in the stratum (such as calcium carbonate and magnesium carbonate), resulting in groundwater with higher elemental concentrations than those observed in surface water [27]. Earlier studies have shown differences in otolith microelement concentrations between freshwater and seawater environments [28] [29]. On the southwest coast of Taiwan, the concentration of magnesium is highest in the seawater, second in groundwater, and lowest in surface water [30], and the concentration of manganese is highest in groundwater, second in surface water, and lowest in sea water [31]. Thus, the chemical composition of otoliths (in the zone near the nucleus) from black porgy hatchery fry changed near groundwater may be different than that of the wild black porgy.

In the present study, the chemical composition of otoliths between the nucleus zone and the edge zone was analyzed in hatchery-reared, recaptured marked 
and wild unmarked black porgy. This is the first time that this method has been applied in Taiwan, and it may be an important tool for the identification of stocks, stocking assessment and management of fisheries.

\section{Methods}

\subsection{The Specimens from Hatchery Reared}

Specimens were obtained from the hatchery of Tainan County on the southwest coast of Taiwan from January to May, 2007. The fish were bred and reared in the hatchery under various salinity conditions for approximately ten months (for specimens A, B and C) or for approximately two months (for specimens D, E, and $F$ ). The total length of each specimen was measured to within $0.1 \mathrm{~cm}$, and the body weight was measured to within $0.1 \mathrm{~g}$ (Table 1).

\subsection{The Specimens from Marked and Recaptured Experiment}

Approximately 108,000 hatchery reared black porgy fry that were $4.6-8.4 \mathrm{~cm}$ in length were mass marked and released for estimating their population size and stocking contribution rate by spraying fluorescent pigment onto the skin of the fry after they were fed with oxytetracycline, creating a double mass-marking method. The marked fry were released at the Baishatun which located in Miaoli County in Northwestern Taiwan between July and September of 2005 [4]. After that, recovery samples were collected by local retailers and brought back to the lab twice a month from December 2005 to August 2006. The types of fishing in the stocking area are mainly bottom gill nets, hand lines and angling hand lines. The researcher would reconfirm the marks after the sample is attended [4]. There were three marked black porgy (for specimens G, H and I) and ten unmarked black porgy (for specimens J, K, L, M, N, O, P, Q, R and S) had be analyzed in this study (Table 1).

\subsection{Otolith Preparation}

In the laboratory, the otolith (sagitta) was removed from specimen, washed and rinse the surface mucosa with de-ionized water, and used the ultrasonically oscillate (Model 1210R-DTH, Branson) for three minutes, then the otolith was placed into the oven to dry at $50^{\circ} \mathrm{C}$ for 24 hours. After that the dried otolith was embedded with epoxy resin, and then the otolith sample resin was fixed on a glass slide, ground with a Metaserv 2000 Grinder-Polishers and sandpaper to near the core, and polished the surface with polishing cloths and $0.05 \mu \mathrm{m}$ alumina abrasive. Polished otolith was fixed to a glass slide using a crystalline bond, dried in an oven at $50^{\circ} \mathrm{C}$ for 24 hours, and stored until further analysis.

\subsection{Laser Ablation ICPMS}

In order to understand the continuity change of the element concentration on the otolith this study to confirm the difference of element concentration ratios between the core area and the edge area of the otolith by the laser ablation sampling system. 
Table 1. Specimen data and identification results of otolith for black porgy using LA-ICPMAS method.

\begin{tabular}{|c|c|c|c|c|c|c|c|c|c|c|c|}
\hline \multirow{2}{*}{$\begin{array}{c}\text { Specimen } \\
\text { code }\end{array}$} & \multirow{2}{*}{$\begin{array}{c}\text { Sampling } \\
\text { time }\end{array}$} & \multirow{2}{*}{$\begin{array}{c}\text { Length } \\
(\mathrm{cm})\end{array}$} & \multirow{2}{*}{$\begin{array}{c}\begin{array}{c}\text { Weight } \\
(\mathrm{g})\end{array} \\
270.7\end{array}$} & \multirow{2}{*}{$\begin{array}{c}\begin{array}{c}\text { Sample } \\
\text { description }\end{array} \\
\text { HR }\end{array}$} & \multicolumn{2}{|c|}{$\begin{array}{l}\text { Range of } \mathrm{Mg}^{2+} / \mathrm{Ca}^{2+} \\
\text { ratio in the central area } \\
\text { of the nucleus zone }\end{array}$} & \multirow{2}{*}{$\begin{array}{c}\begin{array}{c}\text { similar to an } \\
\text { inverse "V" } \\
\text { shape }\end{array} \\
\text { clear }\end{array}$} & \multicolumn{2}{|c|}{$\begin{array}{l}\text { Range of } \mathrm{Mn}^{2+} / \mathrm{Ca}^{2+} \\
\text { ratio in the central area } \\
\text { of the nucleus zone }\end{array}$} & \multirow{2}{*}{$\begin{array}{l}\text { similar to a } \\
\text { "U" shape } \\
\text { clear }\end{array}$} & \multirow[t]{2}{*}{ Identification } \\
\hline & & & & & $1.0 \mathrm{E}-0.4$ & $1.5 \mathrm{E}-0.3$ & & $0.2 \mathrm{E}-0.3$ & $3.1 \mathrm{E}-0.3$ & & \\
\hline B & Jan, 2007 & 18.1 & 108.6 & HR & $3.0 \mathrm{E}-0.4$ & $1.2 \mathrm{E}-0.3$ & unclear & ND & ND & unclear & \\
\hline $\mathrm{C}$ & Jan, 2007 & 17.4 & 87.2 & HR & $0.2 \mathrm{E}-0.3$ & $1.75 \mathrm{E}-0.3$ & clear & ND & ND & unclear & \\
\hline $\mathrm{D}$ & May, 2007 & 6.2 & 4.3 & HR & $5.0 \mathrm{E}-0.4$ & $1.8 \mathrm{E}-0.3$ & clear & $0.5 \mathrm{E}-0.3$ & $7.0 \mathrm{E}-0.3$ & clear & \\
\hline $\mathrm{E}$ & May, 2007 & 5.7 & 3.5 & HR & $4.0 \mathrm{E}-0.4$ & $1.6 \mathrm{E}-0.3$ & unclear & $4.0 \mathrm{E}-0.4$ & $3.0 \mathrm{E}-0.3$ & clear & \\
\hline $\mathrm{F}$ & May, 2007 & 4.9 & 1.9 & $\mathrm{HR}$ & $3.0 \mathrm{E}-0.4$ & $2.0 \mathrm{E}-0.3$ & clear & $0.2 \mathrm{E}-0.3$ & $6.2 \mathrm{E}-0.3$ & clear & \\
\hline G & May, 2006 & 11.8 & 29.2 & $\mathrm{RM}$ & $5.0 \mathrm{E}-0.4$ & $3.6 \mathrm{E}-0.3$ & clear & $3.0 \mathrm{E}-0.4$ & $1.1 \mathrm{E}-0.3$ & clear & \\
\hline $\mathrm{H}$ & Jun, 2006 & 12.5 & 33.6 & $\mathrm{RM}$ & $5.0 \mathrm{E}-0.4$ & $2.4 \mathrm{E}-0.3$ & clear & $2.0 \mathrm{E}-0.4$ & $0.2 \mathrm{E}-0.3$ & clear & \\
\hline I & Jun, 2006 & 15.6 & 58.7 & $\mathrm{RM}$ & $7.0 \mathrm{E}-0.4$ & $1.8 \mathrm{E}-0.3$ & clear & ND & ND & unclear & \\
\hline $\mathrm{J}$ & Feb, 2006 & 14.8 & 60.2 & $\mathrm{CU}$ & $5.0 \mathrm{E}-0.4$ & $2.0 \mathrm{E}-0.3$ & clear & $1.0 \mathrm{E}-0.4$ & $6.0 \mathrm{E}-0.4$ & clear & Hatchery reared \\
\hline K & Feb, 2006 & 13.1 & 55.7 & $\mathrm{CU}$ & $5.0 \mathrm{E}-0.4$ & $1.1 \mathrm{E}-0.3$ & unclear & $1.0 \mathrm{E}-0.4$ & $3.0 \mathrm{E}-0.4$ & unclear & Wild \\
\hline $\mathrm{L}$ & Mar, 2006 & 14.1 & 44.4 & $\mathrm{CU}$ & $5.0 \mathrm{E}-0.4$ & $2.1 \mathrm{E}-0.3$ & clear & $2.0 \mathrm{E}-0.4$ & $1.2 \mathrm{E}-0.3$ & clear & Hatchery reared \\
\hline M & Dec, 2005 & 9.7 & 15.3 & $\mathrm{CU}$ & $4.0 \mathrm{E}-0.4$ & $2.7 \mathrm{E}-0.3$ & clear & $4.0 \mathrm{E}-0.4$ & $1.4 \mathrm{E}-0.3$ & unclear & Hatchery reared \\
\hline $\mathrm{N}$ & Dec, 2005 & 17.2 & 69.7 & $\mathrm{CU}$ & $5.0 \mathrm{E}-0.4$ & $1.7 \mathrm{E}-0.3$ & clear & $0.2 \mathrm{E}-0.3$ & $1.6 \mathrm{E}-0.3$ & unclear & uncertain \\
\hline $\mathrm{O}$ & Feb, 2006 & 14.9 & 78.1 & $\mathrm{CU}$ & ND & ND & unclear & $5.0 \mathrm{E}-0.4$ & $2.4 \mathrm{E}-0.3$ & unclear & Wild \\
\hline $\mathrm{P}$ & Aug, 2006 & 37.6 & 1022.1 & $\mathrm{CU}$ & $6.0 \mathrm{E}-0.4$ & $1.15 \mathrm{E}-0.3$ & unclear & $2.5 \mathrm{E}-0.4$ & $1.5 \mathrm{E}-0.3$ & clear & Hatchery reared \\
\hline Q & Aug, 2006 & 27.2 & 461.6 & $\mathrm{CU}$ & $0.8 \mathrm{E}-0.3$ & $1.9 \mathrm{E}-0.3$ & clear & $-0.1 \mathrm{E}-0.4$ & $3.8 \mathrm{E}-0.4$ & clear & Hatchery reared \\
\hline $\mathrm{R}$ & Dec, 2005 & 17.9 & 119.5 & $\mathrm{CU}$ & $4.0 \mathrm{E}-0.4$ & $1.75 \mathrm{E}-0.3$ & clear & ND & ND & unclear & Hatchery reared \\
\hline S & Dec, 2005 & 16.5 & 73.1 & $\mathrm{CU}$ & $4.0 \mathrm{E}-0.4$ & $1.18 \mathrm{E}-0.3$ & unclear & ND & ND & unclear & Wild \\
\hline
\end{tabular}

HR: Hatchery reared sample; RM: Recptured marked sample; CU: Captured unmarked sample; ND: No data.

The ICPMS laser ablation sampling system is to ablate the surface of the otolith with a high-energy laser and then carry it into the ICPMS for analysis.

The otolith sample was placed on the laser ablation platform, and the laser was focused on the sample points, after that the elements on the surface of the sample were ionized and analyzed by an inductively coupled plasma mass spectrometer. The Limit of detection (LOD) was between about 0.5 and $20 \mathrm{ppb}$.

The size of each ablation pit was $150 \mu \mathrm{m}$ in diameter and the distance between the ablation points is $24-26 \mu \mathrm{m}$. There are $105-303$ ablation points per crossing line. The continuity of the element concentration on otolith was analyzed by detected from the edge through the core to the other edge.

Six trace elements, $\mathrm{Mg}^{2+}, \mathrm{Mn}^{2+}, \mathrm{Ba}^{2+}, \mathrm{Sr}^{2+}, \mathrm{Na}^{+}$and $\mathrm{Ca}^{2+}$ were analyzed, and the concentration ratios of the prior five elements over the major (Calcium) element are shown in Figure 1. In addition, a frame in the nucleus zone of the otolith indicated the approximate growth size of $5 \mathrm{~cm}$.

\section{Results}

Six specimens from the hatchery and thirteen captured samples involved three marked and ten unmarked specimens from seawater of Maoli County were 


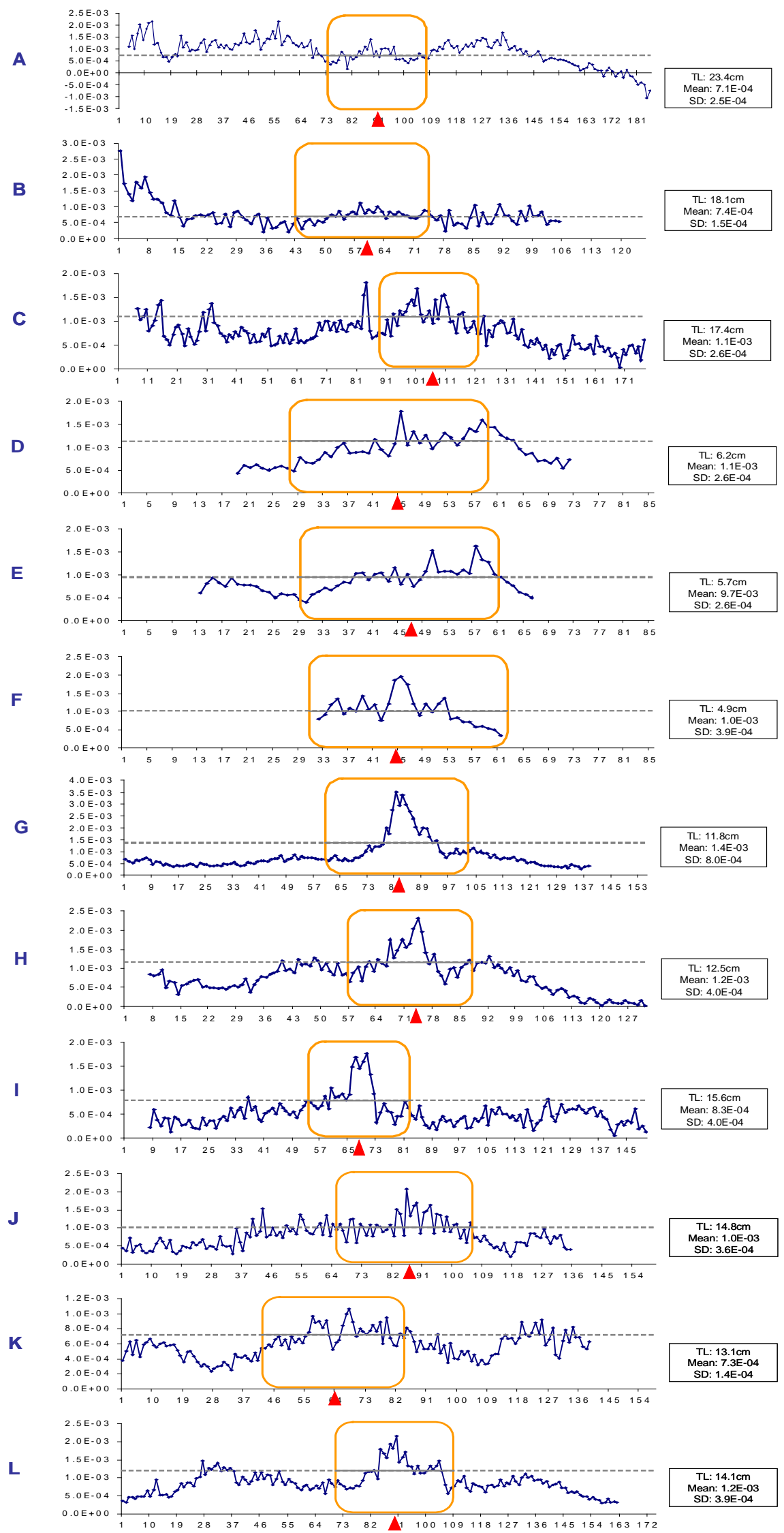




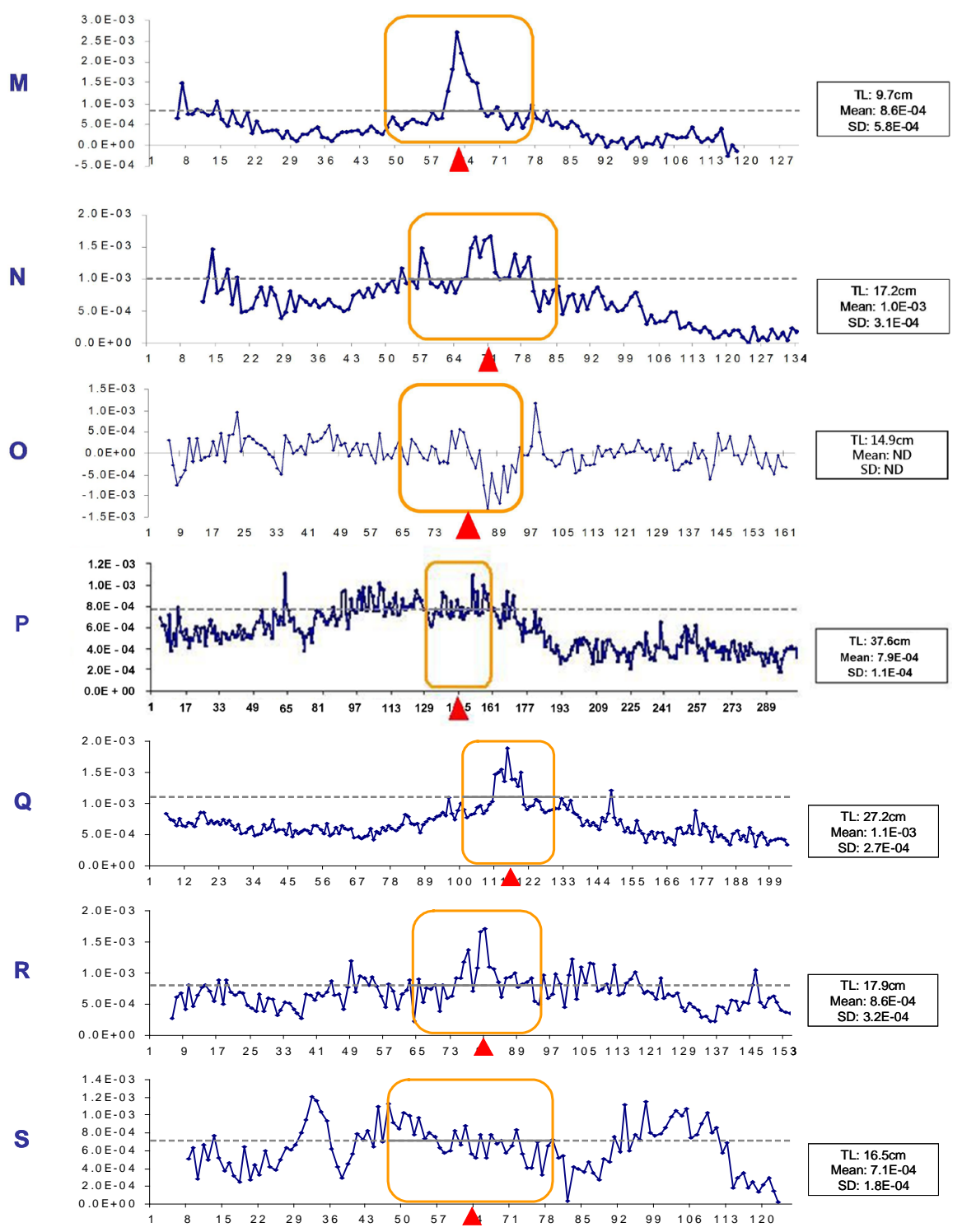

Figure 1. The ratio of magnesium and calcium in the otolith of six hatchery reared specimens (A, B, C, D, E, and F), three recaptured marked specimens $(G, H$ and $I)$ and ten captured unmarked specimens (J, K, L, M, N, O, P, Q, R and S). The horizontal axis showed the analysis point number, and the vertical axis showed the ratio of magnesium and calcium. The frame indicated the nucleus zone of the otolith, the triangle indicated the core of the nucleus zone and the dotted line indicated the average value of the concentration in the nucleus zone of the otolith. TL: Total length of specimen. Mean: The mean value of the concentration in the nucleus zone of the otolith. SD: The standard deviation value of the concentration in the nucleus zone of the otolith. ND: No data.

analyzed for trace element patterns in the otolith. Hatchery specimens A, B, and C were $17.4-23.4 \mathrm{~cm}$ (mean, $19.6 \pm 3.3 \mathrm{~cm}$ ) in length and $87.2-270.7 \mathrm{~g}$ (mean, $155.5 \pm 100.3 \mathrm{~g}$ ) in weight. Hatchery specimens D, E, and F were $4.9-6.2 \mathrm{~cm}$ (mean, $5.6 \pm 0.7 \mathrm{~cm}$ ) in length and $1.9-4.3 \mathrm{~g}$ (mean, $3.2 \pm 1.2 \mathrm{~g}$ ) in weight. Marked specimens G, H, and I were $11.8-15.6 \mathrm{~cm}$ (mean, $13.3 \pm 2.0 \mathrm{~cm}$ ) in length and $29.2-58.7 \mathrm{~g}$ (mean, $40.5 \pm 15.9 \mathrm{~g}$ ) in weight. Unmarked specimens J, 
$\mathrm{K}, \mathrm{L}, \mathrm{M}, \mathrm{N}, \mathrm{O}, \mathrm{P}, \mathrm{Q}, \mathrm{R}$ and $\mathrm{S}$ were $9.7-37.6 \mathrm{~cm}$ (mean, $18.3 \pm 8.2 \mathrm{~cm}$ ) in length and $15.3-1022.1 \mathrm{~g}$ (mean, $200.0 \pm 315.8 \mathrm{~g}$ ) in weight (Table 1).

The relatively high $\mathrm{Mg}^{2+} / \mathrm{Ca}^{2+}\left(1.4 \times 10^{-3}\right)$ ratio observed in the central area of the nucleus zone gradually decreased to both sides $\left(0.3 \times 10^{-3}\right.$ and $\left.0.6 \times 10^{-3}\right)$ in A. Similarly, relatively high values in the central area gradually decreased to both sides in C, D, F, G, H, I, J, L, M, N, Q and R. The higher values shown in the central area within the frame were clearly similar to an inverse " $V$ " shape (Figure 1).

A relatively low $\mathrm{Mn}^{2+} / \mathrm{Ca}^{2+}\left(0.3 \times 10^{-3}\right)$ ratio was observed in the central area of the nucleus zone, and this ratio gradually increased to both sides $\left(2.0 \times 10^{-3}\right.$ and $3.5 \times 10^{-3}$ ) in A. Similarly, D, E, F, G, H, J, L, P and Q showed relatively low values in the central area and gradually increasing levels on both sides. The lower values shown in the central area within the frame were clearly similar to a " $U$ " shape, except in B and C, which could not be evaluated due to experimental errors (Figure 2).

Importantly, the patterns of $\mathrm{Ba}^{2+} / \mathrm{Ca}^{2+}, \mathrm{Sr}^{2+} / \mathrm{Ca}^{2+}$ and $\mathrm{Na}^{2+} / \mathrm{Ca}^{2+}$ did not show any universal trends.

According to the appeared shape of $\mathrm{Mg}^{2+} / \mathrm{Ca}^{2+}$ and $\mathrm{Mn}^{2+} / \mathrm{Ca}^{2+}$ ratio in the central area of the nucleus zone, this study determined the specimen J, L, M, P, Q and $\mathrm{R}$ were from hatchery reared and $\mathrm{K}, \mathrm{O}, \mathrm{S}$ were from wild (Table 1 ).

\section{Disscussion}

Under reflected light, two types of crystals could be found on the surface of the otolith in the nucleus zone (relative to within $5 \mathrm{~cm}$ growth size) of this species. The first type is regular; one ring was formed every day until the $25^{\text {th }}$ day of rearing. In the portion formed from the $25^{\text {th }}$ to approximately the $35^{\text {th }}-65^{\text {th }}$ day, the crystal type was irregular [9].

The divalent metal element with the highest concentration in local sea water was $\mathrm{Mg}^{2+}$, with $\mathrm{Ca}^{2+}$ and $\mathrm{Sr}^{2+}$ ranking second and third, respectively [30]. However, we found that the highest concentration of divalent metal elements in otoliths was $\mathrm{Ca}^{2+}$, followed by $\mathrm{Sr}^{2+}$ and $\mathrm{Mn}^{2+}$. Thus, the formation of otoliths cannot be explained entirely by passive diffusion. The incorporation of $\mathrm{Ca}^{2+}$ into the otoliths is an active process that requires energy in both seawater and freshwater [32] [33], while the incorporation of other divalent trace elements in otoliths, such as $\mathrm{Sr}^{2+}, \mathrm{Mg}^{2+}, \mathrm{Mn}^{2+}$ and $\mathrm{Ba}^{2+}$, is passive and is mainly affected by diffusion.

Because the trace elements were sampled along the longest axis through the central core of the otolith, their distribution patterns tend to be symmetrical. The pattern of $\mathrm{Mg}^{2+}$ on the otoliths demonstrated an inverse "V" shape in specimens $\mathrm{B}, \mathrm{C}, \mathrm{D}$ and $\mathrm{F}$ because the concentration of $\mathrm{Mg}^{2+}$ in seawater was much higher than that observed in freshwater. However, the pattern of $\mathrm{Mn}^{2+}$ on the otoliths showed a " $U$ " shape in specimens $\mathrm{D}, \mathrm{E}$ and $\mathrm{F}$ because the concentration of $\mathrm{Mn}^{2+}$ in sea water was much lower than that in freshwater in this area [25] [26]. The salinity during the hatching process is generally maintained to approximately $30 \%$ of that in seawater to improve the hatching rate of fertilized 
A

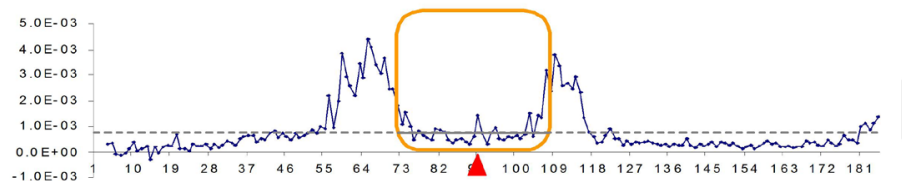

Ti: $23.4 \mathrm{~cm}$
Mean: 79204 Mean: $7.9 E-04$
SD: $5.3 \mathrm{E}-04$

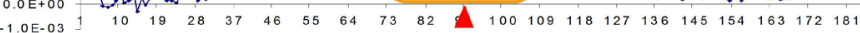

B

$2.0 E-04$
$0.0 E+00$

$0.0 E+00$
$-5.0 E-04$
$-1.0 E-00$
$-2.0 E$

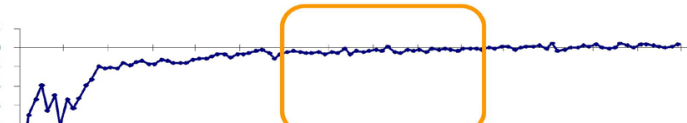

$-1.5 E-03$
$-2.0 E-03$

$-2.5 \mathrm{E}-03$

$-3.0 \mathrm{E}-03$

$\Delta$

Mean: ND
SD: ND

C

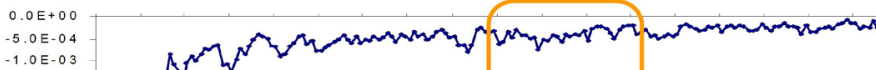

$-1.5 \mathrm{E}-03$

$-5,0 \mathrm{E}-03$

$2.5 \mathrm{E}-0.03$

A

$\begin{array}{llllllllllllllll}11 & 121 & 131 & 141 & 151 & 161 & 17\end{array}$

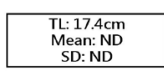

$8.0 \mathrm{E}-0$
$7.0 \mathrm{E}-0$
$6.0 \mathrm{E}-0$
-40

$7.0 \mathrm{E}$
$6.0 \mathrm{E}$
$5.0 \mathrm{E}$
$4.0 \mathrm{E}$
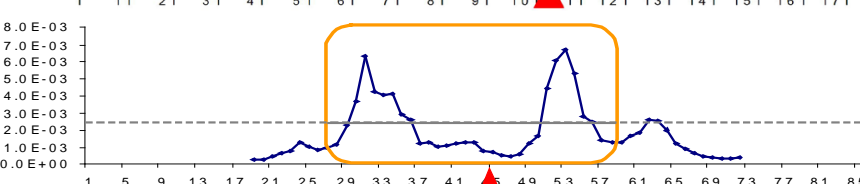

E

$\left.\begin{array}{l}4.0 \mathrm{E} .03 \\ 3.5 \mathrm{E}-03 \\ 3.0 \mathrm{E}-03 \\ 2.03\end{array}\right]$

$2.5 \mathrm{E}-03$
$2.0 \mathrm{E}-0.3$
$1.5 \mathrm{E}-03$
5.03

$1.5 \mathrm{E}-0.0$
$1.0 \mathrm{E}-0$
$5.0 \mathrm{E}-04$
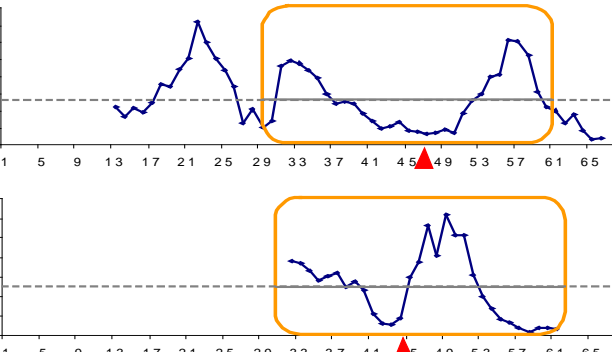

$7.0 \mathrm{E}-03$
$6.0 \mathrm{E}-03$
$5.0 \mathrm{E}-03$
$3.0 \mathrm{E}$
3.03

$\mathbf{F}$

$5.0 \mathrm{E} \cdot 03$
$4.0 \mathrm{E} \cdot 03$
$3.0 \mathrm{E}-03$
1.03

$3.0 \mathrm{E}-03$
$2.0 \mathrm{E}-03$
$1.0 \mathrm{E}-03$

$1.0 \mathrm{E}=03$
$0.0 \mathrm{E}+00$

$1.2 \mathrm{E}-03$

$1.0 \mathrm{E}-0$
$8.0 \mathrm{E}-0$
$8.0 \mathrm{E}-04$

G

$6.0 \mathrm{E}-04$

$4.0 \mathrm{E}-04$

$2.0 \mathrm{E}-04$
$0.0 \mathrm{E}+00$

$\begin{array}{llllllllllllllllllll}9 & 13 & 17 & 21 & 25 & 29 & 33 & 37 & 41 & 45 & 49 & 53 & 57 & 61 & 65 & 69 & 73 & 77 & 81 & 85\end{array}$

Mean: 1.3.3-03
SD: $83 \mathrm{E}-04$

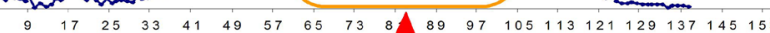

Mean: 6.7E-04 SD: $2.0 E-04$

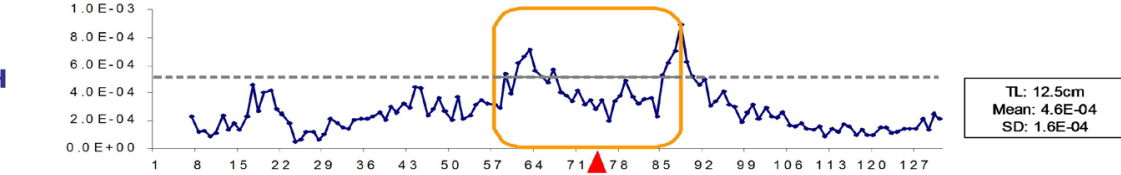

$6.0 \mathrm{E}-04$

$4.0 E-04$

$2.0 \mathrm{E}-04$

$0.0 E+00$

$-2.0 \mathrm{E}-04$

$-4.0 \mathrm{E}-04$
$-6.0 \mathrm{E}-04$

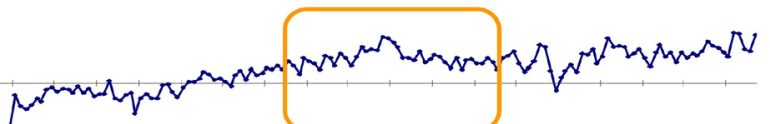

8189

$\left.\begin{array}{l}7.0 E-04 \\ 6.0 E-04 \\ 5.0 E-04 \\ 3.0 E\end{array}\right]$

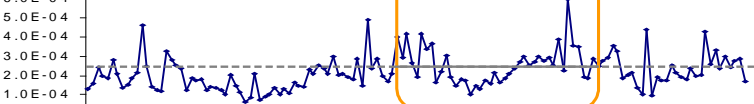

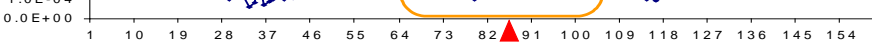

$5.0 \mathrm{E}-04$
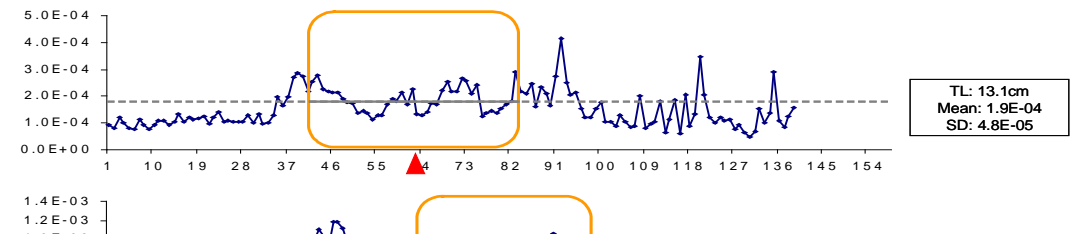

$1.4 \mathrm{E}-03$
$1.2 \mathrm{E}-03$
$1.0 \mathrm{E}-03$
$8.0 \mathrm{E}$

$1.0 \mathrm{E}-03$
$8.0 \mathrm{E}-04$
6.04

$6.0 \mathrm{E}-04$
$4.0 \mathrm{E}-04$

$2.0 \mathrm{E} \cdot 04$

$0.0 \mathrm{E}+00$
$-2.0 \mathrm{E}-04$

$\begin{array}{llllllllllllllll}19 & 28 & 37 & 46 & 55 & 4 & 73 & 82 & 91 & 100 & 109 & 118 & 127 & 136 & 145 & 154\end{array}$ 


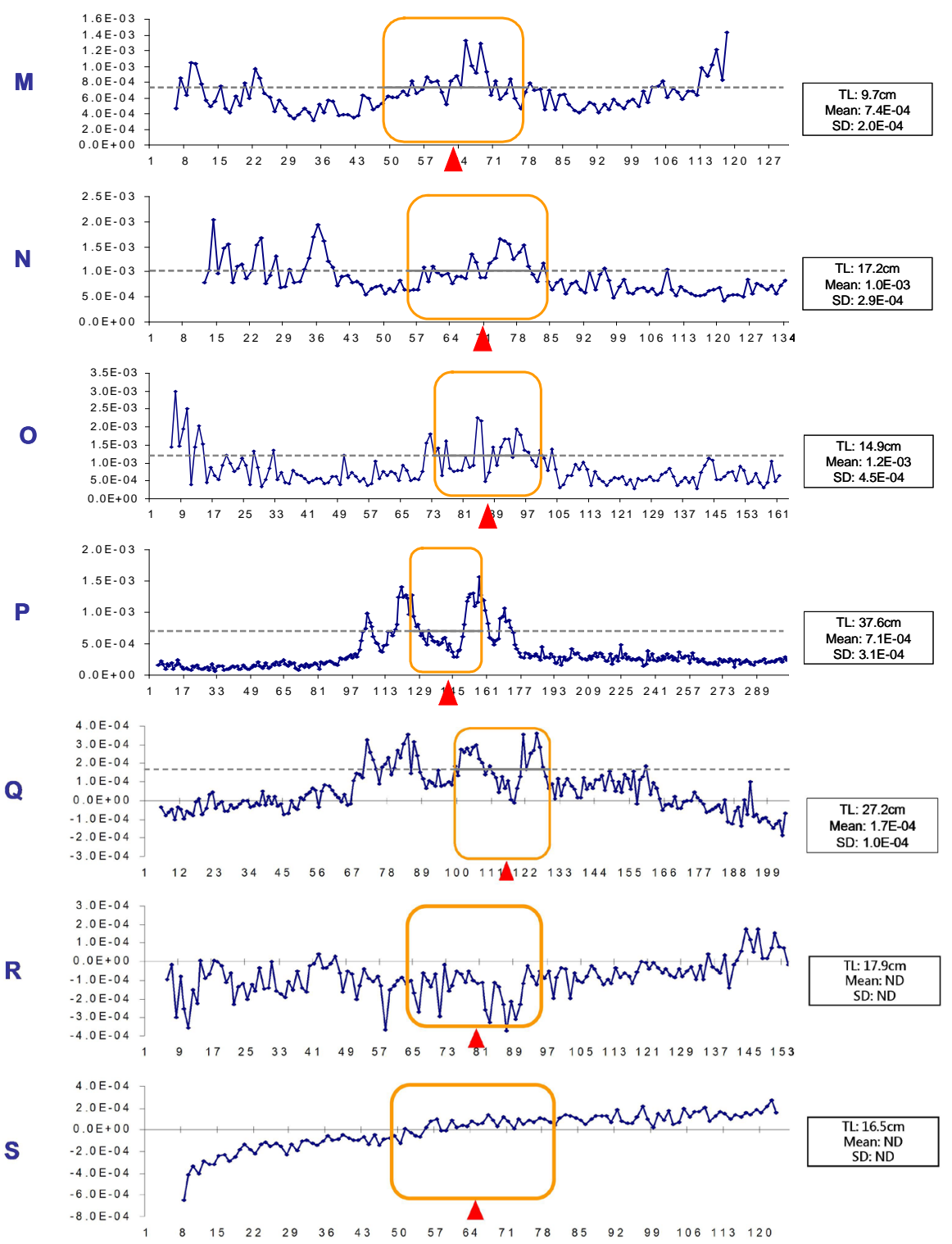

Figure 2. The ratio of manganese and calcium in the otolith of six hatchery reared specimens ( $A, B, C, D, E$, and F), three recaptured marked specimens ( $G, H$ and I) and ten captured unmarked specimens (J, K, L, M, N, O, P, Q, R and S). The horizontal axis represents the analysis point number, and the vertical axis displays the ratio of manganese and calcium. The frame indicates the nucleus zone of the otolith, the triangle indicates the core of the nucleus zone and the dotted line indicates the average value of concentration in the nucleus zone of the otolith. TL: Total length of specimen. Mean: The mean value of concentration in the nucleus zone of the otolith. SD: The standard deviation value of concentration in the nucleus zone of the otolith. ND: No data.

eggs. After two weeks, fresh ground water, which has lower $\mathrm{Mg}^{2+}$ and higher $\mathrm{Mn}^{2+}$ concentrations compared to seawater, is generally added, to decrease the salinity to $15 \%-20 \%$, which promotes the growth of larvae prior to feeding [25] [26]. This change in salinity explains why the trace element distribution patterns along the measured axis in the nucleus zone of otoliths demonstrated an inverse "V" shape for $\mathrm{Mg}^{2+}$ and a " $\mathrm{U}$ " shape for $\mathrm{Mn}^{2+}$. There were several samples with 
negative values and could not be discriminated. The reasons may come from 1) the content of elements were too low to detect, 2) the instrument was not stable, or 3) the elements were not equidistribution deposited when otolith were formed, which lead to an asymmetrical trend crossing through the core area and could not be discriminated.

The $\mathrm{Ba}^{2+}$ concentration patterns in the otolith specimens did not show a clear regular trend, perhaps because $\mathrm{Ba}^{2+}$ is a land-based element in which the concentration varies in ground water and because it is found less in otoliths [30]. Similarly, the $\mathrm{Sr}^{2+}$ concentration pattern did not show any clear regular trends in the otolith specimens, potentially because $\mathrm{Sr}^{2+}$ is abundant in both the ground water of southwestern Taiwan [34] and in seawater [33]; thus, despite the reduction in the salinity of seawater to approximately $15 \%-20 \%$ during hatching, the concentration of $\mathrm{Sr}^{2+}$ in the otoliths remained at high levels.

Gillanders and Munro (2009) [35] used the Inductively Coupled Plasma-Mass Spectrometer (ICP-MS) method to analyze the Mg:Ca ratio in the otoliths of the small-mouth hardy head Atherinosoma microstoma along the Coorong, South Australia. They found a significant positive linear relationship with the $\mathrm{Mg}: \mathrm{Ca}$ ratio in the water. The $\mathrm{Mg}^{2+}$ level exhibited a positive linear relationship with the salinity range $(5-160 \mathrm{~g} / \mathrm{L})$ of water. Other studies have shown similar patterns for salinities between 0 and $40 \mathrm{~g} / \mathrm{L}$ [36] [37]. These results were similar to those observed for the otoliths of black porgy, and higher $\mathrm{Mg}^{2+}$ concentrations have been observed in seawater compared to brackish water. Although $\mathrm{Mg}^{2+}$ is a common constituent of seawater, its concentrations in fresh water are generally $1 / 100^{\text {th }}$ of those observed in seawater [38]. In this study, the $\mathrm{Mg}^{2+}$ concentrations in the otoliths might display a pattern that could reflect the concentration changes in the growth environments.

Arai and Hirata (2006) [29] also found that the trace element concentrations in the otoliths reflected the differences in freshwater and seawater environments by analyzing the concentrations of $\mathrm{Mg}^{2+}$ and $\mathrm{Mn}^{2+}$ in the otoliths of chum salmon Oncorhynchus keta. However, in their study, the $\mathrm{Mg}^{2+}$ concentration in the freshwater growth zone was higher than that in seawater, which was in contrast to our results for juvenile black porgy.

It is unclear how $\mathrm{Mg}^{2+}$ is absorbed into the otoliths from the low concentrations observed in freshwater. Juvenile salmon most likely have an active absorption mechanism. Juvenile salmon would also be able to obtain $\mathrm{Mg}^{2+}$ using active absorption from freshwater even in environments with lower $\mathrm{Mg}^{2+}$ concentrations; however, mature salmon in seawater need to absorb less $\mathrm{Mg}^{2+}$ for physiological reasons, even in environments with higher $\mathrm{Mg}^{2+}$ concentrations.

Studies of the chum salmon Oncorhynchus keta using LA-ICPMS could not distinguish the environmental changes by interpreting the $\mathrm{Mn}^{2+}$ levels because the average concentration values showed no significant difference [29], which suggested that the use of trace element distribution trend patterns in these studies may be novel to precisely determine environmental changes.

This study showed six specimens were from hatchery reared among ten un- 
marked specimens captured from wild. This phenomenon showing the wild population of black porgy with a high proportion was from hatchery reared in this sea area (Table 1). Gonzalez et al. (2008) [39] described the similar condition of black porgy in Hiroshima Bay because of the frequently stocking practices. However, this is also shown that detection of $\mathrm{Mg}^{2+} / \mathrm{Ca}^{2+}$ and $\mathrm{Mn}^{2+} / \mathrm{Ca}^{2+}$ ratio in the central area of the nucleus zone of otolith could be an effective tool to distinguish black porgy came from hatchery reared or wild without using artificial marks.

In the Mediterranean, Swan et al. (2006) [28] found that the entire otolith of the European hake Merluccius merluccius from the Gulf of Lions was characterized by significantly higher concentrations of $\mathrm{Mn}^{2+}$ relative to other seawater bodies, which might be due to the freshwater input into this region. An earlier study found that the concentration of $\mathrm{Mn}^{2+}$ was relatively high in river water compared to seawater [40]. These results were similar to this study, in which $\mathrm{Mn}^{2+}$ levels increased while the salinity of seawater decreased to approximately $15 \%-20 \%$ during hatching (due to the addition of freshwater). However, the lower concentrations of $\mathrm{Sr}^{2+}$ observed in the European hake [28] differed from those observed in black porgy in this study, potentially due to the freshwater that was added, which was groundwater containing higher concentrations of $\mathrm{Sr}^{2+}$. Recent studies have shown that the ratio of trace element concentration of otolith could reflect the change of elements, salinity or water temperature [41] as a tool to know about the fish migration between freshwater and sea water [42] [43], which is also a future application of this study.

Taken together, the most important findings in this study were that $\mathrm{Ca}^{2+}$ was absorbed by an active mechanism, while both $\mathrm{Mg}^{2+}$ and $\mathrm{Mn}^{2+}$ were acquired by passive diffusion during the juvenile stage of black porgy development.

In the future, the addition of a higher concentration $\mathrm{Mg}^{2+}$ and $\mathrm{Mn}^{2+}$ solution during the juvenile stage of stocking species could be used as an origin mark for detection after recapture.

\section{Acknowledgements}

The authors would like to thank the Taiwan Fisheries Sustainable Development Association for providing the fry. We are grateful for the assistance of the Da-Sheng commercial aquaculture hatchery. Financial support from the Council of Agriculture, Republic of China (94AS-14.1.1-FA-F1-19, 95AS-14.1.1-FA-F1-19, 96AS-15.1.1-FA-F1-9 and 97AS-15.1.1-FA-F1-5) is also much appreciated.

\section{Conflicts of Interest}

The authors declare no conflicts of interest regarding the publication of this paper.

\section{References}

[1] Kuo, C.L. (2002) Experiments regarding Marked and Released of Marine Species in 
Taiwan. Acta Oceanographica Taiwanica, 40, 13-20. (In Chinese)

[2] Wu, C.C. (2007) The Fry Release Standard Operational Procedure. Proceedings Taiwan Fisheries Sustainable Development Association, Vol. 5, Keelung City, 19-22. (In Chinese)

[3] Chang, W.C., Lee, Y.C. and Shih, C.H. (2008) The Determination of Mass Marking Methods with High Marks Retention Rate for Hatchery-Reared Fry. Journal of the Fisheries Society of Taiwan, 35, 185-194.

[4] Chang, W.C., Lee, Y.C., Shih, C.H., Chu, T.J. and Chang, P.H. (2011) Population Size and Stocking Contribution Rates for Marked and Recaptured Black Porgy Acanthopagrus schlegelli, in Northwestern Taiwan, 2005-2008. Fisheries Research, 109, 252-256. https://doi.org/10.1016/j.fishres.2011.02.009

[5] Chang, K.H. and Wu, W.L. (1977) Tagging Experiments on the Spotted Mackerel (Scomber australasicus) in Taiwan. Bulletin of the Institute of Zoology, Academia Sinica, 16, 137-139.

[6] Anonymous (1993) The Conservation Outcome of Fisheries Resources. Taiwan Fisheries Bureau Press, Taipei City. (In Chinese)

[7] Begg, G.A. and Waldman, J.R. (1999) An Holistic Approach to Fish Stock Identification. Fisheries Research, 43, 35-44. https://doi.org/10.1016/S0165-7836(99)00065-X

[8] Levy, J.A., Maggioni, R. and Conceição, M.B. (1998) Close Genetic Similarity among Populations of the White Croaker (Microponias furnieri) in the South and South-Eastern Brazilian Coast. I. Allozyme Studies. Fisheries Research, 39, 87-94. https://doi.org/10.1016/S0165-7836(98)00166-0

[9] Huang, W.B. and Chiu, T.S. (1997) Daily Increments in Otoliths and Growth Equation of Black Porgy, Acanthopagrus schlegeli, Larvae. Acta Zoologica Taiwanica, 8, 121-131.

[10] Campana, S.E., Fowler, A.J. and Jones, C.M. (1994) Otolith Elemental Fingerprinting for Stock Identification of Atlantic Cod (Gadus morhua) Using Laser Ablation (ICPMS). Canadian Journal of Fisheries and Aquatic Sciences, 51, 1942-1950. https://doi.org/10.1139/f94-196

[11] Campana, S.E. (1999) Chemistry and Composition of Fish Otoliths: Pathways, Mechanisms and Applications. Marine Ecology Progress Series, 188, 263-297. https://doi.org/10.3354/meps188263

[12] Griffiths, M.H. (1996) Age and Growth of South African Silver Cob, Argyrosomus inodorus (Sciaenidae), with Evidence for Separate Stocks. South African Journal of Marine Science, 17, 37-48. https://doi.org/10.2989/025776196784158419

[13] Gillanders, B.M. (2001) Trace Metal in Four Structures of Fish and Their Use for Estimates of Stock Structure. Fishery Bulletin, 99, 410-419.

[14] Radtke, R.L. and Shafer, D.J. (1992) Environmental Sensitivity of Fish Otolith Microchemistry. Australian Journal of Marine and Freshwater Research, 43, 935-951. https://doi.org/10.1071/MF9920935

[15] Thresher, R.E., Proctor, C.H., Gunn, J.S. and Harrowfield, I.R. (1994) An Evaluation of Electron Probe Microanalysis of Otoliths for Stock Delineation and Identification of Nursery Areas in Southern Temperature Groundfish, Nemadactylus macropterus (Cheilodactylidae). Fishery Bulletin, 92, 817-840.

[16] Milton, D.A., Chenery, S.R., Farmer, M.J. and Blaber, S.J.M. (1997) Identifying the Spawning Estuaries of the Tropical Shad, Terubok Tenualosa toli, Using Otolith Microchemistry. Marine Ecology Progress Series, 153, 283-291. 
https://doi.org/10.3354/meps153283

[17] Gray, A. (1985) Solid Sample Introduction by Laser Ablation for Inductively Coupled Plasma Source Mass Spectrometry. Analyst, 110, 551-556. https://doi.org/10.1039/an9851000551

[18] Denoyer, E.R., Fredeen, K.J. and Hager, J.W. (1991) Laser Solid Sampling for Inductively Coupled Plasma Mass Spectrometry. Analytical Chemistry, 63, 445-475. https://doi.org/10.1021/ac00008a718

[19] Hall, G.E.M. (1992) Inductively Coupled Plasma Mass Spectrometry in Geoanalysis. Journal of Geochemical Exploration, 44, 201-249. https://doi.org/10.1016/0375-6742(92)90051-9

[20] Kalish, J.M. (1989) Otolith Chemistry: Validation of the Effects of Physiology, Age and Environment on Otolith Composition. Journal of Experimental Marine Biology and Ecology, 132, 151-178. https://doi.org/10.1016/0022-0981(89)90126-3

[21] Bath, G.E., Thorrold, S.R., Jones, C.M., Campana, S.E., McLaren, J.W. and Lam, J.W.H. (2000) Strontium and Barium Uptake in Aragonitic Otoliths of Marine Fish. Geochimica et Cosmochimica Acta, 64, 1705-1714. https://doi.org/10.1016/S0016-7037(99)00419-6

[22] Elsdon, T.S. and Gillanders, B.M. (2004) Fish Otolith Chemistry Influenced by Exposure to Multiple Environmental Variables. Journal of Experimental Marine Biology and Ecology, 313, 269-284. https://doi.org/10.1016/j.jembe.2004.08.010

[23] Thorrold, S.R., Jones, C.M., Campana, S.E., McLaren, J.W. and Lam, J.W.H. (1998) Trace Element Signatures in Otoliths Record Natal River of Juvenile American Shad (Alosa sapidissima). Limnology and Oceanography, 43, 1826-1835. https://doi.org/10.4319/lo.1998.43.8.1826

[24] Ashford, J.R., Arkhipkin, A.I. and Jones, C.M. (2006) Can the Chemistry of Otolith Nuclei Determine Population Structure of Patagonian Toothfish Dissostichus eleginoides? Journal of Fish Biology, 69, 708-721. https://doi.org/10.1111/j.1095-8649.2006.01144.x

[25] Kai, F.M. (2000) Analyzing the Course of Land Subsidence in Coastal Areas of Yunlin County. Master's Thesis, National Taiwan University Graduate Institute of Geosciences, Taiwan.

[26] Su, M.S. (2000) Establish an Internationally Competitive Sustainable Marine Aquaculture Industry. Fish World Magazine, 24, 14-20.

[27] Hem, J.D. (1992) Study and Interpretation of the Chemical Characteristics of Natural Water. USGS Water-Supply Paper 2254, 38-39.

[28] Swan, S.C., Geffen, A.J., Morales-Nin, B., Gordon, J.D.M., Shimmield, T., Sawyer, T. and Massutí, E. (2006) Otolith Chemistry: An Aid to Stock Separation of Helicolenus dactylopterus (Bluemouth) and Merluccius merluccius (European Hake) in the Northeast Atlantic and Mediterranean. ICES Journal of Marine Science, 63, 504-513. https://doi.org/10.1016/j.icesjms.2005.08.012

[29] Arai, T. and Hirata, T. (2006) Determination of Trace Elements in Otoliths of Chum Salmon Oncorhynchus keta by Laser Ablation-ICP-Mass Spectrometry. Fisheries Science, 72, 977-984. https://doi.org/10.1111/j.1444-2906.2006.01246.x

[30] Anonymous (2006) Environmental Water Quality Monitoring Annual 2006s Report-Groundwater Quality Articles. EPA Taiwan Press, Taiwan.

[31] Liao, I.C., Kuo, C.L., Yu, T.C. and Tzeng, W.N. (1994) Release and Recovery of Japanese Eel, Anguilla japonica, in Taiwan. Journal of Taiwan Fisheries Research, 2, $1-6$. 
[32] Cruz, S., Shiao, J.C., Liao, B.K., Huang, C.J. and Hwang, P.P. (2009) Plasma Membrane Calcium ATPase Required for Semicircular Canal Formation and Otolith Growth in the Zebrafish Inner Ear. Journal of Experimental Biology, 212, 639-647. https://doi.org/10.1242/jeb.022798

[33] Shelley, R.U., Zachhuber, B., Sedwick, P.N., Worsfold, P.J. and Lohan, M.C. (2010) Determination of Total Dissolved Cobalt in UV-Irradiated Seawater Using Flow Injection with Chemiluminescence Detection. Limnology and Oceanography: Methods, 8, 352-362. https://doi.org/10.4319/lom.2010.8.352

[34] Lin, S.H. (2012) Migratory Environmental History and Habitat Use of Japanese Eel Anguilla japonica in the River as Revealed by Otolith Elemental Composition and Mark-Recapture Experiment. Ph.D. Dissertation, National Taiwan University, Taiwan.

[35] Gillanders, B.M. and Munro, A.R. (2009) Relations between Water Chemistry, Otolith Chemistry and Salinity of a Hypersaline System: Implications for Determining Past Environmental History of Fish. CSIRO: Water for a Healthy Country National Research Flagship, CSIRO Canberra, ACT.

[36] Surge, D.M. and Lohmann, K.C. (2002) Temporal and Spatial Differences in Salinity and Water Chemistry in SW Florida Estuaries: Effects of Human-Impacted Watersheds. Estuaries, 25, 393-408. https://doi.org/10.1007/BF02695982

[37] Dorval, E., Jones, C.M., Hannigan, R. and van Montfrans, J. (2005) Can Otolith Chemistry Be Used for Identifying Essential Seagrass Habitats for Juvenile Spotted Seatrout, Cynoscion nebulosus in Chesapeake Bay? Marine and Freshwater Research, 56, 645-653. https://doi.org/10.1071/MF04179

[38] Spaargeren, D.H. (1991) The Biological Use of Chemical Elements: Selection on Environmental Availability and Electron Configuration. Oceanologica Acta, 14, 569-574.

[39] Gonzalez, E.B., Umino, T. and Nagasawa, K. (2008) Stock Enhancement Programme for Black Sea Bream, Acanthopagrus schlegelii (Bleeker), in Hiroshima Bay, Japan: A Review. Aquaculture Research, 39, 1307-1315. https://doi.org/10.1111/j.1365-2109.2008.01996.x

[40] Broecker, W.S. and Peng, T.H. (1982) Tracers in the Sea, Lamont-Doherty Earth Observatory. Palisades, New York.

[41] Williams, J., Jenkins, G.P., Hindell, J.S. and Swearer, S.E. (2018) Fine-Scale Variability in Elemental Composition of Estuarine Water and Otoliths: Developing Environmental Markers for Determining Larval Fish Dispersal Histories within Estuaries. Limnology and Oceanography, 63, 262-277.

https://doi.org/10.1002/lno.10627

[42] Shao, Y., Farkas, J., Holmden, C., Mosley, L., Kell-Duivestein, I., Izzo, C., Reis-Santos, P., Tyler, J., Torber, P., Fryda, J., Taylor, H., Haynes, D., Tibby, J. and Gillanders, B.M. (2018) Calcium and Strontium Isotope Systematics in the Lagoon Estuarine Environments of South Australia: Implications for Water Source Mixing, Carbonate Fluxes and Fish Migration. Geochimica et Cosmochimica Acta, 239, 90-108. https://doi.org/10.1016/j.gca.2018.07.036

[43] Walsh, C.T. and Gillanders, B.M. (2018) Extrinsic Factors Affecting Otolith Chemistry-Implications for Interpreting Migration Patterns in a Diadromous Fish. Environmental Biology of Fishes, 101, 905-916. https://doi.org/10.1007/s10641-018-0746-y 